\title{
INTEGRASI PELAYANAN SOSIAL UNTUK MEMBANTU PENYESUAIAN DIRI LANJUT USIA (STUDI KASUS DI BALAI PERLINDUNGAN SOSIAL TRESNA WERDHA CIPARAY KABUPATEN BANDUNG)
}

\author{
Ishak Fadlurrohim¹, Soni Akhmad Nulhaqim²dan Nandang Mulyana ${ }^{3}$ \\ ${ }^{1}$ Program Magister Kesejahteraan Sosial, Fakultas Ilmu Sosial dan Ilmu Politik, Universitas Padjadjaran \\ ${ }^{2}$ Program Pascasarjana, Fakultas Ilmu Sosial dan Ilmu Politik, Universitas Padjadjaran \\ E-mail: ishakfadlurrohim@gmail.com ; soni.nulhaqim@unpad.ac.id ; mulyananandang@yahoo.com
}

\begin{abstract}
ABSTRAK. Masalah utama yang dihadapi lanjut usia adalah penurunan kesehatan fisik dan mental yang membuat penyesuaian diri terhadap pelayanan sosial meliputi lingkungan alamiah, diri sendiri dan lingkungan sosial nya. Penelitian ini bertujuan mengetahui Integrasi Pelayanan sosial di Balai Perlindungan Sosial Tresna Werdha Ciparay yang mempengaruhi proses penyesuaian diri lanjut usia dalam menghadapi penolakan terhadap dirinya maupun lingkungan sosialnya. Terutama menghadapi proses transformasi dalam kehidupan, Penelitian menemukan bahwa Peningkatan pelaksanaan dan pengembangan lembaga pelayanan sosial menjadi salah satu hal penting dalam menilai mutu dan kualitas suatu lembaga terutama pelayanan sosial terhadap lanjut usia yang semakin dibutuhkan. Di sisi lain diakibatkan karena lemahnya kemampuan pengorganisasian dan manajerial sebagai keahlian dan keterampilan yang dibutuhkan dalam menyelenggarakan kegiatan pelayanan sosial. kemampuan dan keterampilan manajerial dan organisasi merupakan salah satu aspek yang penting dalam menciptakan integrasi pelayanan sosial yang mempengaruhi kondisi lanjut usia yang tinggal di panti dalam menerima perubahan kondisi baik secara fisik maupun mental. Budaya organisasi menjadi salah satu kendala terwujudnya integrasi pelayanan sosial baik organisasi formal maupun informal yang membentuk intervensi pelaksanaan pelayanan sosial untuk membentuk penyesuaian diri lanjut usia selama ada di panti.
\end{abstract}

Kata kunci: Integrasi; Lanjut Usia; Penyesuaian Diri; Pelayanan Sosial

\section{INTEGRATION OF SOCIAL SERVICES TO HELP ELDERLY ADJUSTMENTS AGE (SOCIAL PROTECTION INSTITUTION OF ELDERLY PEOPLE CIPARAY BANDUNG REGENCY)}

\begin{abstract}
The main problem faced by the elderly is the decline in physical and mental health that makes oneself compared to the social environment, oneself and the social environment. This research focuses on the integration of social services at the Tresna Werdha Ciparay Social Protection Center which influences the initial renewal process. Most of the transformation process in life, the study found that an increase in the implementation and development of social service institutions became one of the important things in achieving the quality and quality of social service institutions to increase the results needed. On the other hand, it is caused due to the weak organizing ability and expertise as expertise needed in social training activities. Managerial and organizational skills and skills are one of the important aspects in developing social contributions that improve the conditions of the elderly who live in institutions in accepting changes in conditions both physically and mentally. Organizational culture is one that plans social development with both formal and informal organizations that make social work interventions to arrange for the elderly while in the institution.
\end{abstract}

Key words: Integration; Elderly; Self Adjustment; Social Services

\section{PENDAHULUAN}

Sebagian penjelasan pengaruh dari peristiwaperistiwa kehidupan seperti kehilangan pasangan, atau pindah ke panti jompo, tidak memiliki semangat hidup, yang mempercepat kematian mereka. Masalah utama yang dihadapi lanjut usia adalah penurunan kesehatan fisik dan mental yang membuat penyesuaian diri terhadap pelayanan sosial meliputi lingkungan alamiah, diri sendiri dan lingkungan sosialnya (Alex Sobur, 2013).

Definisi lanjut usia berbeda tergantung negara yang mengimplementasikan program dan sistem (Brandle, et. al 2007:19). Negara Indonesia menentukan seseorang yang berusia 60/ 70 tahun keatas disebutLanjut Usia. Hal ini terdapat di Undang-Undang No. 13 Tahun 1998 tentang Kesejahteraan Lanjut Usia pasal 1 Ayat 2. Seiring berjalannya waktu jumlah populasi lanjut usia sekarang meningkat. Menurut (Pelaez \& Kalache, 2001) Lanjut Usia merupakan kelompokdengan perkembangan paling pesat di dunia dan membuat masalah yang berhubungan kepada pengasuhan keluarga memberikan perawatan yang dibutuhkan (Maeda, 2000: 32). Sehingga mempengaruhi terwujudnya pelayanan sosial yang berkaitan dengan pemenuhan Hak Asasi Manusia terutama lanjut usia.

Perkembangan penduduk usia tua di indonesia berkembang pesat, pada saat 2017 sekitar 23, 66 Juta Jiwa lanjut usia, meningkat hampir 3.4 Juta Jiwa dari jumlah sebelumnya di tahun 2014 (Survey Sensus Nasional 2017). Memperhatikan data yang ditunjukkan, diprediksikan jumlah lanjut usia di dunia pada tahun 2020 meningkat dengan 27.08 Juta Jiwa, selanjutnya di tahun 2025 mencapai 33.69 Juta, lima tahun selanjutnya mencapai 40.49 Juta Jiwa di tahun 2030 dan pada tahun 2035 mencapai 48.19 Juta Jiwa (Kementerian Kesehatan RI, 2017). Perkembangan lanjut usia menunjukkan struktur usia penduduk di negara berubah menuju periode lanjut usia. Struktur dewasa akhir pada tahun 2020 , yaitu $10 \%$ penduduk Indonesia berusia 60 tahun atau lebih (Kementerian Kesehatan RI, 2017). 
Situasi ini menunjukkan dampak kondisi sosial, ekonomi terhadap keluarga, komunitas atau negara. Dampak ini meperlihatkan secara makro peningkatan rasio ketergantungan di tahun 2017 adalah 14,20 artinya 100 orang penduduk usia kerja menanggung sekitar 14 lanjut usia (Badan Pusat Statistik, 2017). Melihat lanjut usia terus mengalami perkembangan berpengaruh pada pemenuhan kebutuhan akan tempat tinggal, makanan dan pakaian untuk memenuhi kebutuhan dasar serta perawatan dan keamanan lanjut usia. Hal ini memunculkan bentuk pelayanan sosial yang dibuat oleh negara, swasta maupun swadaya dalam melindungi dan mewujudkan kesejahteraan lanjut usia.

Penghuni panti werdha tidak mempunyai sumber daya dikarenakan kerentanan dan kemiskinan yang dialami menjadikan tersisihkan. Kondisi kemiskinan yang dimaksud adalah kemiskinan primer dan sekunder. Hal ini yang menjadi latar belakang lanjut usia tinggal di Panti Werdha.

Pelayanan sosial dapat merepresentasikan bagaimana negara menjalankan fungsi perlindungan dan perawatan lanjut usia. (Alfred J Khan, 1981) menjelaskan pelayanan sosial adalahsuatu layanan meliputi program yang dimunculkan dengan mengesampingkan mekanisme pasar dalampemenuhan kebutuhan dasarbaik fasilitas kesehatan, pendidikan dan kesejahteraan bertujuan meningkatkan keberfungsian sosial serta untuk memudah kanjangkauan dan aksesibilitas layanan bagi lembaga masyarakat yang mengalami kesulitan.

Program pelayanan sosial yang ada akan memiliki dampak penerimaan diri lanjut usia dalam penye-suaian diri. Penerimaan diri sendiri Sheerer dalam (Cronbach, 1963) menjelaskan sebagai sikap menilai personal dan kondisi sekitarnya dengan objektif, mampu menerima segala hal termasuk kelebihan dan kekurangan. Artinya menyadari, memahami dan menerima diri dengan sebaik baiknyadiikuti dengan niat serta kemampuan mengembangkan diri menjadi menjalankan keseharian dengan baik dan penuh tanggung jawab (Heart, 2007). Para lanjut usia sendiri mengalami proses kemunduran baik fisik dan mental meliputi indera perasa, suara, mulut, kulit, kemampuan motorik, intelektual, sistem saraf dan otot, pernafasan, jantung, seksualitas mempengaruhi aktifitas sehari-hari. Secara umum lanjut usia menjalani hidup digolongkan menjadi dua sikap yaitu masa tua diterima secara normal dengan kesadaran mendalam atau sebaliknya tidak menerima masa tua dengan menyangkal kenyataan.

Konsep pelayanan sosialsendiri merupakan kegiatan yang diberikan wewenang untuk kepentingan bersama. Tidak selalu harus kolektif, terdapat pelayanan individu tetapi dilakukan secara konsensus demi kepentingan bersama dalam rangka pemenuhan kebutuhan.

Selain itu Sandford dalam (Huruswati, 2013) mengemukakan penyebab sulitnya menjalankan integrasi pelayanan sosial adalah terdapat konflik kepentingan diantara berbagai pimpinan lembaga/ institusi yang memberikan pelayanan sejenis. Namun Sandford menyampaikan tidak terintegrasi pelayanan sosial dan tidak berkelanjutan dikarenakan budaya organisasi yang tidak fokus dalam mengatasi pemenuhan kebutuhan dan penaganan masalah lanjut usia.

Melihat berbagai perkembangan pelayanan sosial yang ada didunia dengan pelayanan sosial yang terintegrasi, tentunya berpengaruh terhadap penyesuaian diri lanjut usia akan lingkungan alamiah, diri sendiri dan lingkungan sosial selama tinggal di panti. Berdasarkan hal tersebut, maka penting untuk mengkaji bagaimana integrasi pelayanan sosial dalam membantu penyesuaian diri lanjut usia di BPSTW Ciparay. Serta bertujuan untuk menggambarkan integrasi layanan yang efektif dan efisien.

Pendekatan Provan dan Milward (2001) adalah perspektif yang mereka adopsi ketika mempelajari jaringan. terdapat tiga perspektif bisa dibedakan, masingmasing mengungkap berbagai aspek berbeda dari jaringan organisasi. Beberapa penulis berfokus antara organisasi. Disatu sisi melihat ikatan (perspektif-ego). Ketiga menekankan pentingnya mengambil hubungan antara semua hal yang relevan ke dalam satu hal. Pandangan terakhir mempelajari hasil tertentu pada tingkat jaringan yang lengkap (Provan et al., 2007). Maka dari beberapa hal tersebut dapat memperlihatkan proses integrasi pelayanan sosial untuk membantu penyesuaian diri lanjut usia di panti.

\section{METODE}

Metode penelitian yang digunakan pada Integrasi Pelayanan Sosial untuk Penyesuaian Diri Lanjut Usia di Balai Perlindungan Sosial Tresna Werdha Ciparay Kabupaten Bandung adalah menggunakan pendekatan kualitatif yang pada dasarnya untuk menghasilkan data deskriptif.

Penelitian menggunakan in depth interview, observasi partisipatif dan studi dokumentasi dengan memperhatikan uji kredibilitas data meliputi ketekunan pengamatan, triangulasi sumber, teknik, waktu serta kecukupan referensi selanjutnya hasil penelitian ini dilakukan uji transferabilitiy yaitu pengujian hasil penelitian dilakukan secara jelas, komprehensif dan sistematis dan dapat di pertanggung jawabkan dengan membuat laporan. Selanjut nya melakukan uji dependability dan confirmability dimana dimaksudkan sebagai langkah mengaudit langkah yang diperoleh melalui konsultasi kepada tenaga ahli meliputi konsultan pemerhati lanjut usia, sehingga data yang dihasilkan benar-benar dapat dipertanggung jawabkan.

\section{HASIL DAN PEMBAHASAN}

Balai Perlindungan Sosial Tresna Werdha Ciparay menjalankan peran dan fungsi di bidang pelayanan dan perlindungan sosial sebagai unit pelaksana teknis. Balai 
Perlindungan Sosial Tresna Werdha sendiri didirikan tahun 1979/1980 dengan surat keputusan Menteri Sosial RI No.41/Huk/Kep/X/79 tanggal 1 November 1979 dengan nama Sasana Tresna Werdha Pakutandang dan mulai beroperasi tanggal 19 Mei 1980. Berdasarkan Surat Keputusan Menteri Sosial RI No. 32/Huk/Kep/V/1982 tanggal 1 November 1982 yang selanjutnya berubah menjadi PSTW Pakutandang.

Berjalannya waktu, pada saat otonomi daerah berkembang berganti nama menjadi PSTW Pakutandang dari Peraturan Daerah No. 5 Tahun 2002 tentang Perubahan atas Peraturan Daerah No 15 Tahun 2000. Selanjutnya berganti nama kembali menjadi Balai Perlindungan Sosial Tresna Werdha Ciparay dan menjadi induk dari 3 instansi PSTW yaitu PSTW Jiwa Baru Garut, PSTW Sukma Raharja Bogor dan PSTW Budi Daya Karawang. Pada akhirnya Tahun 2009 berdasarkan Peraturan Gubernur Jawa Barat No. 113 Tahun 2009 tentang Organisasi dan Tata Kerja Unit Pelaksana Teknis Dinas dan Badan di Lingkungan Pemerintah Provinsi Jawa Barat diikuti penambahan dan perubahan nama instalasi menjadi Sub Unit Rumah Perlindungan Sosial Tresna Werdha (RPSTW) Garut, Bogor, Karawang dan ditambah dengan Sub Unit Pemeliharaan Taman Makam Pahlawan Cikutra Bandung.

Selain itu BPSTW memiliki Tugas Pokok dalam menjalankan peran dan fungsi bidang pelayanan dan perlindungan sosial lanjut usia terlantar dan pemeliharaan taman makam pahlawan. Selain itu sebagai bahan pengkajian pelaksanaan pedoman/ petunjuk teknis pelayanan dan perlindungan lansia terlantar dan pemeliharaan taman makam pahlawan serta penyelenggaraan pelayanan sosial dan perlindungan sosial lansia terlantar dan pemeliharaan taman makam pahlawan.

Balai Perlindungan Sosial Tresna Werdha Ciparay memiliki Struktur organisasi meliputi Kepala Panti, Sub Bagian Tatausaha, Seksi Penerimaan dan Penyaluran, Seksi Pelayanan Kesejahteraan Sosial, Jabatan fungsional dan kepala sub unit. Selain itu memiliki visi menjadi penyediaan layanan terbaik Indonesia Tahun 2018 dengan mewujudkan lanjut usia yang memiliki harkat, martabat dan kualitas kesehatan yang prima, membangun sistem serta mekanisme layanan lanjut usia, mendorong sumber daya manusiakompeten dalam pelaksanaan fungsi dan peran, memberikan fasilitas pendukung pelayanan lanjut usia yang sesuai dan menciptakan netwoking untuk meningkatkan kualitas layanan suatu institusi/ lembaga. Hal lain yang menjadi moto BPSTW Ciparay adalah Panca Satya Pelayanan yaitu membuat keamanan dan kenyamanan untuk lanjut usia, penyediaan pelayanan dan perlindungan tanpa pamrih/ ikhlas, penyaluran minat, bakat dan potensi lanjut usia, menanamkan nilai kejuangan, keperintisan dan kepeloporan serta menciptakan kondisi berwawasan lingkungan
Balai Perlindungan Sosial Tresna Werdha Ciparay sendiri didukung oleh tenaga pengelola berjumlah 53 orang Pegawai Tetap (PNS) dan 6 orang tenaga penunjang. Pegawai tetap meliputi 4 Struktural, 9 Fungsional Umum, 5 Fungsional Tertentu dan 4 Pekerja Sosial serta Pegawai Tidak Tetap meliputi 3 Tenaga Administrasi, 2 Penjaga Kebun, 4 Petugas keamanan, 4 Petugas kebersihan, 5 Juru masak, 3 perawat dan 10 Pramu werdha. Selain itu penerimaan lanjut usia dapat berasal dari dinas sosial, sub unit, masyarakat, organisasi sosial, individu/ keluarga dan instansi dimana memiliki syarat diantaranya mengisi forma permohonan yang telah disediakan, berusia60 tahun keatas, sehat fisik dan mental, mengikuti peraturan, adanya penjamin dari pihak keluarga/ wali dan membawa surat pindah dari daerah asal. Setelah itu lanjut usia diberikan program dalam pemenuhan kebutuhan dasar, aksesibilitas sarana dan prasarana, kesehatan, fisik, sosial, mental dan spiritual, pemberdayaan, sosialisasi dan koordinasi dan perlindungan hingga terminasi meliputi dirujuk ke lembaga lain, meninggal dunia, kembali ke keluarga atau mandiri. Untuk mendukung fungsi pelayanan terdapat kegiatan supervisi yaitu merupakan kegiatan pengawasan untuk mengetahui pelaksanaan kegiatan sesuai dengan tugas pokok dan fungsibertujuan mengoptimalisasi tenaga sumber daya manusia dalam pelaksanaan kegiatan di lembaga. Kegiatan supervisi bersifat konsultatif kepada supervisor dalam mengatasi permasalahan yang dihadapi melihat kebijakan, prosedur dan rencana kerja. Monitoring yaitu sistem pengawasan yang dilaksanakan oleh penanggungjawab kegiatan yang bertujuan memastikan kegiatan yang berjalan ataupun akan datang sesuai dengan rencana dan sumber daya yang ada. Evaluasi yaitu menilai keberhasilan dan kegagalan program pelayanan yang ada sebagai bentuk pertanggung jawaban pihak balai maupun sub unit kepada penerima layanan, keluarga atau pemerintah. Pelaporan yaitu informasi kegiatan terlaksana, hambatan yang dihadapi, alternatif dan masukan dalam mengatasi setiap masalah yang dihadapi. Kegiatan ini dilaksanakan sebagai tanggungjawab dan pelaporan pelaksanaan kegiatan dan dilakukan secara berkala.

Penyelenggaraan tugas pokok dan fungsi Balai Perlindungan Sosial Tresna Werdha Ciparay sebagai unit pelaksana teknis dinas dapat dilaksanakan secara optimal dengan ketersediaan sumber daya manusia yang mampu memberikan pelayanan dengan prima, dukungan kelengkapan sarana dan prasarana, adanya kerjasama dengan masyarakat, tokoh masyarakat, organisasi sosial dan instansi terkait.

Fenomena lanjut usia yang dibawa oleh keluarga untuk ditempatkan di panti dengan berbagai cara yang dilakukan agar dapat tinggal dan memperoleh layanan. Seperti halnya lanjut usia yang datang bersama anaknya untuk mendaftar. Terdapat pula kasus, sang anak yang mengantarkan lansia ke panti tidak mengakui sebagai orang tuanya, tetapi melainkan lanjut usia yang ditemukan atau terlantar di jalan. Sementara itu si anak memberitahukan 
kepada orang tua/ lanjut usiayang akan dimasukan ke panti untuk berbohong dengan tidak mengakui dirinya sebagai anaknya. Hal itu dilakukan agar mendapatkan perawatan dan memperoleh fasilitas kesehatan yang ada di panti. Kondisi ini membuat lanjut usia terkadang merasa terpaksa dan terdesak untuk mengikuti permintaan anaknya tersebut. Peristiwa tersebut menggambarkan bahwa terdapat permasalahan dalam pengelolaan pelayanan sosial di panti tersebut, sehingga permasalahan tersebut muncul. Apakah terdapat kesalahan dalam kebijakan atau dikarenakan rendahnya pengawasan terhadap pelaksanaan, atau lemahnya control, atau mungkin kurang terintegrasinya pengelolaan pelayanan sosial. Peningkatan pelaksanaan dan pengembangan lembaga pelayanan sosial menjadi salah satu hal penting dalam mempertahankan mutu dan kualitas suatu lembaga pelayanan sosial bagi lanjut usia.Kurangnya kemampuan pengorganisasian dan manajemen menjadi salah satu faktor utama terhambatnya penyelenggaraan layanan. Selain itu kemampuan dan keterampilan manajemen serta tata kelola organisasi merupakan salah satu aspekpenting dalam menciptakan pelayanan sosial terpadu (terintegrasi). Keahlian-keahlian tersebut diasumsikan dapat mempengaruhi kondisi lanjut usia yang tinggal di panti dalam menerima perubahan kondisi baik secara fisik maupun mental menjadi lebih baik lagi.

Pada sebagian lembaga pelayanan sosial, seringkali pelayanannya dikelola secara tradisional dan kekeluargaan, tanpa ditunjang dengan kemampuan manajaerial yang memadai. Mereka umumnya mengelola lembaga pelayanan sosial karena dorongan rasa iba semata. Semestinya pelayanan sosial yang baik dan terintegrasi tidaklah cukup hanya mengandalkan niat baik semata. Hal ini kadang menjadikan budaya organsasi yang mengatur pelaksanaan serta pengawasan seperti halnya yang disampaikan tentang integrasi adalah kondisi kelompok-kelompok etnis dapat beradaptasi dan menjadi komformitas terhadap budaya mayoritas, namun mempertahankan budaya mereka sendiri. Atau biasa di sebut terpadu. Myron dalam (Juliardi, 2014) sendiri membagi integrasi menjadi 5 pengertian (a) Integrasi melihat proses penggabungan berbagai kelompok budaya dan sosial di satu lingkungan dan membentuk identitas nasional, membangun rasa kebersamaan dengan menghapus kesetiaan pada kepentingan. (b) Integrasi melihat dari pembuatan wewenang pusat di atas unit-unit sosial yang lebih kecil beranggotakan kelompok sosial budaya masyarakat tertentu. (c) Integrasi melihat hubungan antara pemerintah dan pelaksana. Menyamakan perbedaan-perbedaan aspirasi dan nilai pada kelompok elit dan massa. (d) Integrasi melihat terdapat konsensus terhadap hal kecil, sehingga diperlukan untuk menjaga. (e) Integrasi melihat pembuatan kebiasaan yang terintegrasi dan diterima demi mencapai tujuan bersama.

Konsep integrasi pelayanan sebagai kegiatan yang dilakukan berbagai pihak ditujukan guna menjalankan kepentingan bersama namun bukan artinya sifatnya selalu kolektif dikarenakan memberi layanan terhadap individu dapat dilakukan demi kepentingan penyediaan dan kepentingan bersama yang telah diatur. Menurut Sandfort dalam (Huruswati, 2013) Penyebab sulit dalam pelaksanaan integrasi pelayanan adalah terdapat konflik kepentingan baik pimpinan yang memberikan pelayanan sama. Namun, Sandfort menyampaikan pelayanan sosial yang terintegrasi dan berkelanjutan dikarenakan budaya organisasi yang tidak berfokus pada pemberian layanan pada kegiatan pemenuhan kebutuhan dan penyelesaian masalah.

Secara sederhana dari (Moenir, 2006)pelayanan itu sendiri adalah kegiatan yang dilakukan oleh pihak yang memiliki wewenang untuk pemenuhan kebutuhan dan demi kepentingan bersama namun tidak berarti bersifat kolektif dikarenakan penyediaan layanan bagi perorangan pun dapat di penuhi asalkanatas dasar kepentingan bersama termasuk pemenuhan kebutuhan secara konsensus. Penyediaan pelayanan sosial adalah langkah penting untuk mengurangi angka kemiskinan/ kerentanan agar tingkat kesejahteraan sosial masyarakat menjadi lebih baik. Pelayanan sosial sendiri adalah penyelenggaraan layanan oleh pemerintah ataupun masyarakat sebagai langkah penyediaan kebutuhan dasar, spiritual maupun sosial. Sehingga mampu menjalankan hidup yang sejahtera dan mampu mendorong potensi dirinya agar mampu menjalankan fungsi sosialnya dengan baik. Pelayanan sosial sendiri merupakan serangkaian kegiatan terarah dan memiliki kelembagaan yang bertujuan meningkatkan kualitas kehidupan manusia. Menurut (Suharto, 2009) Secara konseptual kesejahteraan meliputi proses dancara menyejahterakan masyarakat serta menjelaskan sistem layanan sosial dan bentuk perlindungan sosial terhadap kaum rentan.

Hal ini integrasi layanan menunjukkan dapat mengatasi permasalahan dan pemenuhan kebutuhan menggunakan konsep pelayanan sosial. Selain itu Pelayanan Sosial menurut (Siporin, 1975) merupakan penyelenggaraan kegiatan kesejahteraan sosial bertujuan meningkatkan taraf kesejahteraan, kualitas dan kelangsungan hidup melalui rehabilitasi sosial, jaminan sosial, pemberdayaan sosial dan perlindungan sosial. Tujuan utama adalah meningkatkan dan membangun/ menciptakan pribadi dan sistem sosial di masyarakat, pada intinya dilakukan untuk pengembangan, menjaga dan meningkatkat/ mendorong sistem kesejahteraan sosial yang ada.Menurut Alfred J. Khan, Pelayanan Sosial di bagi menjadi 2 bentuk, meliputi :

a. Pelayanan sosial yang kompleks/ rumit dan komprehensif sehingga sulit ditentukan identitasnya. Pelayanan ini seperti pelayanan pendidikan, bantuan sosial dalam bentuk uang oleh pemerintah, perawatan medis dan perumahan rakyat.

b. Pelayanan sosial yang jelas ruang lingkupnya dan pelayanannya walaupun selalu mengalami perubahan. Pelayanan ini mampu berdiri secara mandiri, contohnyalayanan kesejahteraan anak dan keluarga, 
namun dapat pula menjadi suatu bagian dari suatu lembaga layanan, seperti pekerja sosial di pendidikan/ sekolah, pekerja sosial medis/rumah sakitdan pekerjaan sosialindustry/ perusahaan.

Pelayanan sosial sendiri dapat diartikan secara luas sebagai kegiatan pemberian layanan bertujuan membantu meningkatkan taraf kesejahteraan sosialnya sedangkan secara sederhana merupakanlayanan sosial yang diberikan untuk ditujukan kepada golongan masyarakat rentan atau tidak memiliki harapan (Dwi Heru Sukoco, 1991:3). Pelayanan sosial juga dapat diartikan secara sederhana sebagai pelayanan kesejahteraan sosial dimana terdiri dari proses/ tahapan pertolongan dan perlindungan untuk kelompok rentan yang memiliki masalah diantaranya layanan bagi anak terlantar, keluarga fakir miskin, disabilitas dan permasalahan lainnya.Mempelajari tentang meningkatkan kualitas layanan di institusi atau lembaga, hal ini tidak terlepas atau tidak dapat dipisahkan terhadap pandangan dan pemahaman terkait sistem lembaga secara luas. Pendekatan ini disebut Model Sistem Keseluruhan. Pendekatan ini secara sempit melibatkan penilaian untuk ketiga komponen sub-sistem kelembagaan yaitu Masukan, Proses, dan Keluaran.Masukan atau inputialah terdiri dari karakteristik Lembaga, dimana didalamnya meliputi sistem sumber atau fasilitas yang ada dan dimiliki institusi atas dasar untuk membantu mendorong efektivitas dalam pemberian layanan dan memenuhi tujuan organisasi. Di sisi lain proses adalah serangkaian pelaksanaan/ prosedur yang dijalankan suatu organisasi didalam menyediakan bentuk pelayanan kepada penerima manfaat. Pada akhir proses pemberian layanan kepada penerima manfaat setelah menjalani proses, hal inilah yang dimaksud dengan keluaran atau out come (Edi Suharto, 2005 : 186).

Setelah beberapa pembahasan tentang integrasi pelayanan diatas. Maka bentuk pelayanan sosial bagi lanjut usia yang menjadi pembahasan menarik yang ada di lembaga dalam menyelenggarakan layanan sosial di Balai Perlindungan Sosial Tresna Werdha Ciparay. Bentuk pertama adalah model pelayanan sosial dengan model pantiyang menyediakan dan memberikan tempat tinggal penerima pelayanan di suatu lembaga yang memiliki kategori tertentu di sesuaikan dengan jenis pemberian layanannya meliputi perlindungan, bimbingan, perawatan kesehatan yang di fasilitasi pihak lembaga sendiri sebagai bentuk perlindungan kepada masyarakat yang mengalami keterlantaran dan tidak memiliki keluarga. Seperti hal nya pelayanan sosial bagi lanjut usia terdapat pemberian layanan keagamaan dan mental yang ditujukan untuk memberikan kekuatan dan mendorong keyakinan dan menjaga ketakwaan kepada Tuhan. Pemberian bimbingan kerohanian dan mental kepada lanjut usia dilaksanakan melalui kegiatan pertemuan keagamaan yang disesuiakan dengan kebutuhan dan kepercayaan atau agama.

Pendampingan sosial menjadi salah satu strategi dalam memberikan layanan kepada penerima manfaat yang ada di lembaga guna memberikan pelayanan secara langsung. Hal ini Sesuai dengan prinsip pekerjaan sosial, ialah “To Help People To Help Themself”, pendampingan sendiri kepada penerima manfaat dimaksudkan agar ada partisipasi langsung dari penyedia layanan kepada penerima layanan atau dalam hal ini lanjut usiadi Balai Perlindungan Sosial Tresna Werdha Ciparay. Memberikan partisipasi dan bentuk perhatian kepada lanjut usia memberikan wujud rasa empati dan peduli. Pada pembahasan ini dapat terlihat peran/ kapasitas pekerja sosial dapat di munculkan pendamping adalah tidak menjadi seorang pemberi obat atau langsung dapat memecahkan masalah. Pendamping sosial sebagai pelaksana perubahan dengan aktif terlibat kegiatan dalam mengatasi permasalahan yang muncul dari lanjut usia. Maka dapat diartikan sebagai hubungan yang dinamis bagi penerima manfaat dan pekerja sosial yang Bersamasamamengatasi serta menhadapi berbagai permasalahan baik fisik, psikologis dan kesehatan di karenakan proses kemunduran lanjut usia yang memunculkan kompleksitas masalah.

Standarisasi panti memiliki ketentuan yang berisi dan memperhatikan keadaan dan kualitas capaian dari balai perlindungan sosial tresna werdha ciparay sebagai penyelenggara/lembaga pelayanan sosial sejenis lainnya. Terdapat dua jenis standar panti sosial, diantaranya standar panti secara umum dan khusus. Standar panti secara umum yaitu aturan atau wewenang yang memuat kondisi lingkungan sekitar institusi yang memberikan layanan dan kinerja tertentu untuk mencapai tujuan serta memperbaiki pelaksanaan kegiatan yang ada apapun jenis permasalahannya. Sementara itu standar panti secara khusus diartikan meliputi aturan/ wewenang memuat dan berisi hal penting dan perlu perbaikan bagi berjalannya penyelenggaraan panti dan lembaga pelayanan sosial sejenis lainnya disesuaikanke khasan permasalahan yang di tangani panti.

Standar panti secara umum, ialah institusi atau panti sendiri memiliki strutur Kelembagaan, meliputiLegalitas Organisasi,VisidanMisi, OrganisasidanTataKerja,Sumber Daya Manusia (penyelenggara panti, Pengembangangn Personil Panti, fasilitas umum, finansial, pelayanan sosial dasar, Monitoring dan Evaluasi. Maka integrasi layanan sosial memiliki peran dalam membantu lanjut usia dalam menjalani masa tua nya yang berkualitas serta mempromosikan layanan terintegrasi guna mendukung sistem layanan maupun kerja sama antar profesi yang ada di institusi yang memiliki penyelenggaraan layanan yang sejenis. Maka permasalahan yang paling penting adalah proses penyesuaian diri lanjut usia selama berada di panti guna menerima perubahan kondisi lingkungan sosial yang baru.

Penyesuaian diri yang dimaksud merupakan keterampilan menciptakan hubungan yang baik antara orang dan lingkungan sekitarnya. Penyesuaian diri adalah faktor penting dalam berjalannya kehidupan. 
Begitu pentingnya hal ini hingga berbagai literatur mengungkapkan bahwa manusia sejak lahir hingga mati tidak lain adalah penyesuaian diri. Alex Sobur (2013:527) Pada dasarnya menjelaskan penyesuaian diri adalah keterampilanmembangun hubunganyangmenguntungkan antara orang dan lingkungannya. Lingkungan mencakup seluruh hal yang mempengaruhi setiap kemungkinan dan kekuatan di sekitar individu dan berdampak pada kehidupan. Lingkungan tersebut mencakup 3 aspek utama meliputi (a) Lingkungan Alamiah yaitu komponen luar dan hal yang melengkapi di sekitar individu bersifat vital dan dasar, meliputi pakaian, tempat tinggal, makanan dan lainnya. (b) Lingkungan sosial, dapat diartikan berada di masyarakat, karena individu menjalani kehidupan tentunya bersama anggota, adat istiadat dan aturan-aturan menjaga hubungan individu diantara satu sama lain. (c) Manusia itu sendiri (the self), yaitu manusia/ dirinya sendiri adalah berhubungan dengannya diri pribadi yang tentunya memahami dan mempelajari untuk mengatur, menguasai, mengontrol keinginan dan tuntutan yang tidak sesuaidengan dasar logika.

Sehingga dapat di ketahui bahwa aspek-aspek penyesuaian diri berdasarkan teori diatas yaitu penyesuaian diri terhadap lingkungan alamiah, lingkungan sosial dan terhadap dirinya sendiri (the Self). Maksud dari lingkungan alamiah adalah bagaiamana lanjut usia dapat menyesuaikan diri dengan lingkungan alamiah yaitu bentuk yang konkrit seperti dapat menyesuaikan diri dengan tempat tinggal saat ini, makanan dan pakaian. Lingkungan sosial adalah bagaimana lanjutusia melakukan penyesuaian diriterhadap orang-orang di Balai Perlindungan Sosial Tresna Werdha Ciparay seperti berinteraksi sesama lanjut usia, pegawai panti serta lingkungan sekitarnya. Serta bagaimana lanjut usia tersebut dapat menjalankan kesehariannya di dalam Balai Perlindungan Sosial Tresna Werdha.

Menurut Fromm dan Gilmore (dalam Desmita, 2009:195) menjelaskan terdapat 4 bentuk penyesuaian diri yang baik antara lain Pertama, kematangan emosional yaitu kemantapan suasana kehidupan emosional, kemantapan suasana kehidupan kebersamaan dengan orang lain, kemampuan untuk santai, gembira dan menyatakan kejengkelan dan sikap serta perasaan terhadap kemampuan dan kenyataan diri sendiri. Kedua, kemampuan intelektual yaitu kemampuan mencapai wawasan diri sendiri, kemampuan memahami orang lain dan keragamannya, kemampuan mengambil keputusan, keterbukaan dalam mengenal lingkungan. Ketiga, kematangan sosial, yaitu keterlibatan dalam partisipasi sosial, ketersediaan kerjasama, kepemimpinan dan sikap toleransi. Keempat, tanggung jawab (sikap produktif untuk mengembangkan diri, membuat perencanaan dan menjalankan dengan fleksibel, memiliki etika dan jujur". Sehingga dari beberapa penjelasan teori tentang penyesuaian diatas dapat disimpulkan bahwa lingkungan yang ada didalam diri termasuk kematangan emosional, kematangan intelektual dan kemampuan dirinya. Selain itu aspek yang ada di luar dirinya seperti lingkungan sosial, interaksi sosial dan kemampuan sosialnya.

Untuk mengetahui bagaimana manusia menyesuaikan dirinya. Berikut ciri-ciri penyesuaian diri seperti yang di kemukakan oleh (Sunarto dan Hartono, 2008: 224) terdapat ciri-ciri penyesuaian diri meliputi (a) Tidak memperlihatkan adanya ketegangan emosional. (b) Tidakadanya gejala psikologis. (c) Tidak adanya rasa frustasi pribadi. (c) Memiliki pernilaian yang rasional dan mengontrol diri. (d) memiliki keinginan untuk belajar. (e) Menghargai pengalaman. (f) Bersikap realistis dan berpikir objektif.

Apabila melihat dari ciri-ciri penyesuaian diri yang dapat terjadi maka dapat melihat pula bagaimana penyesuaian diri yang baik dan buruk pada lanjut usia seperti halnya yang di jelaskan menurut Hurlock (1980:440), hal yang dapat menunjukkan bentuk penyesuaian diri yang baik dan buruk diantaranya (a) Penyesuaian diri yang baik: Minat kuat dan beragam; Mandiri untuk hidup mandiri; Hubungantidak terbatas dengan orang-orang yang berusia lanjut usia tetapi dengan segala umur; Kepuasan kerja yang menyenangkan dan bermanfaat dengan tidak menghabiskan banyak biaya; Keikutsertaan berpartisipasi dalam organisasi kemasyarakatan; Kemampuan untuk menikmati berbagai kegiatan dengan tidak menyesali masa lampau; Dapat mengurangi kecemasan terhadap diri sendiri maupun orang lain; Menikmati kegiatan atau aktifitas sehari-hari meskipun bersifat berulang-ulang; Dapat menghindari kesalahan-kesalahan khususnya tentang kondisi tempat tinggal dan perlakuan orang lain. (b) Penyesuaian diri yang buruk: Memiliki minat dan peranan yang kecil pada lingkungan; Adanya perasaan yang selalu cemas dan didorong oleh perasaan mengangur; Kurang bersemangat; Masih dipengaruhi oleh masa kejadian-kejadian di masa lalu; Memiliki sifat menarik diri; Bersikap bahwa aktifitas yang ada menjadi hal yang percuma ; Adanya penolakan untuk ikut serta dalam kegiatan orang-orang usia lanjut karena alasan membosankan; Selalu mengeluh dan mengkritik segala sesuatu; Adanya perasaan kesepian sebagai akibat kekakuan hubungan dalam keluarga dan minat yang rendah untuk menjalani kehidupan saat ini.

Berdasarkan uraian tersebut dapat disimpulkan bahwa penyesuaian diri terdiri dari yang baik yaitu lanjut usia dapat menerima perubahan yang terjadi pada dirinya baik itu perubahan usia, status, kemampuan fisik, kemampuan psikis dan intelektual serta terbatasnya penghasilan. Selain itu lanjut usia juga harus mampu menyesuaikan diri dengan kenyataan yang terjadi saat ini sehingga dapat merencanakan kegiatan dimasa mendatang untuk tampil lebih bahagia, sehat meskipun sibuk dengan berbagai kegiatan. Sedangkan penyesuaian diri yang buruk yaitu lanjut usia tidak dapat menerima perubahan yang terjadi pada dirinya baik itu perubahan usia, status, kemampuan fisik, kemampuan psikis dan intelektual serta terbatasnya penghasilan. Menurut Gunarsa dalam Alex Sobur (2003: 
529) menyebutkan bentuk-bentuk penyesuaian diri diklasifikasikan dalam dua bentuk. (a) Penyesuaian Diri yang Adaptive yaitu Bentuk penyesuaian diri yang adaptive sering dikenal dengan istilah adaptasi. Bentuk penyesuaian diri ini lebih bersifat badani, artinya perubahan-perubahan dalam proses badani untuk menyesuaikan diri terhadap keadaan lingkungan. (b) Penyesuaian Diri yang Adjustive yaitu Bentuk penyesuaian diri yang adjustive lebih bersifat keadaan psikis kita, misalnya jika kita harus pergi kerumah tetangga atau teman yang tengah berduka cita karena kematian salah seorang anggota keluarganya, mungkin sekali wajah kita dapat diatur sedemikian rupa, sehingga menampilkan wajah duka. Sebagai tanda ikut menyesuaikan terhadap suasana sedih dalam keluarga tersebut.

Maka penyesuaian diri yang muncul tentunya memiliki perbedaan yang di hasilkan oleh lanjut usia yang memasuki kehidupan baru di dalam panti baik secara positif maupun negatif. Apabila melihat fenomena lanjut usia yang dikecewakan oleh anaknya yang mendaftarkan dirinya kedalam panti dengan cara yang menyakitkan maka perlu proses penyesuaian diri yang berbeda. Hal ini membuat pelayanan sosial yang ada di Balai Perlindungan Sosial Tresna Werdha Ciparay dapat optimal dan terintegrasi. Sebab banyak contoh kasus penolakan yang terjadi baik antara diri lanjut usia terhadap diri nya sendiri maupun lingkungan sosial nya yang diakibatkan oleh penurunan fungsi fisik dan mental. Seperti hal nya dengan rasa kekecewaan lanjut usia tidak mau mengikuti ataupun keluar dari ruangan nya, selain itu uja terdapat penolakan identitas terhadap penilaian yang sudah menjadi warga binaan di panti dengan tidak mau menggunakan baju yang disediakan panti dikarenakan memiliki penilaian yang merendahkan terhadap lanjut usia.

Lanjut usia sendiri menurut (Lilik Ma'rifatul Azizah, 2011:1) mendefinisikan Lanjut usia menjadi bagian proses perkembangan. Manusia tidak secara langsung menjadi lanjut usia, namun melalui perkembangan dimulai bayi, anak, dewasa dan diakhiri menjadi tua. Maka dengan perubahan fisik dan perilaku dapat di perkirakan terjadi kepada semua oranga saat mencapai usia tahapan perkembangan tertentu. Seluruhnya akan mengalami proses menjadi tua di akhir kehidupan dengan kemunduran yang dialami secara fisik, mental dan sosial. selain itu (Tedy Laleno, 1993:20) menyatakan ciri khas lanjut usia yaitu (a) Usia: disebut lanjut usia jika seseorang berusia tua dan mengerti dan menghayatinya sebagai lanjut usia (b) Kematian: merupakan fakta kehidupan bagi semua orang, namun kematian dirasakan dan ditanggapi secara berbeda-beda (c) Intensifikasi: secara umum lanjut usia memikirkan/ merenungkan akan kematian, keyakinan, diri sendiri dan keadaan fisiknya (d) Penyakit: tentunya lanjut usia menghadapi penuruan fisik dikarenakan sakit dan memahami dampaknya terhadap kondisi emosional terhadap semangat dan kekuatan lanjut usia.

Selain pendapat diatas, Tody Lalenoh (1993:23) menyatakan bahwa masalah-masalah yang berkaitan dengan lansia yaitu (a) Orang-orang yang berlanjut usia banyak menimbulkan problema yang berhubungan dengan berkurangnya kemampuan untuk mempertahankan diri, karena menurunnya kesehatan. Ini disebabkan pula oleh proses alamiah kerapuhan fisik dan penyakit yang belum pernah dialami (b) Meningkatnya mutu kesehatan, ekonomi dan sosial memungkinkan terjadinya perlambatan proses ketuaan (panjang umur) dengan tingkat harapan hidup yang semakin tinggi, sehingga populasi dan proporsi usia lanjut akan meningkat (c) Adanya kepercayaan bahwa usia lanjut merupakan masa kemunduran dalam berbagai segi kehidupan sehingga hal tersebut menimbulkan sikap menyerah pada keadaan, pasif dan menunggu nasib (d) Keadaan seksualitas, seperti adanya anggapan bahwa masalah seks adalah milik atau hanya milik orang muda saja. Bila dilihat orientasi masa sekarang, peranan seks dalam tetap berorientasi pada kenikmatan bukan pada reproduksi, sehingga seks sebagai kenikmatan hidupyang penting bagi mereka yang sudah tua bahkan perlu dipelihara dan ditingkatkan (e) Seringkali kita lihat bahwa orang-orang usia lanjut penuh dengan stress akibat dari kemiskinan dan menderita banyak masalah penyakit. Sering kali stress yang dialami tersebut mengakibatkan depresi, kekhawatiran dan paranoid. Masa usia lanjut merupakan masa ketenangan dengan merasakan hasil dan jerih payah yang di hasilkan saat muda dan dewasa.

Sehingga dapat menyadari bahwa mereka berubah menjadi lambat dan pergerakan menjadi kurang baik dibandingkan pada saat muda. Menurunnya kondisi seperti persendian kaku, tangan gemetar, kepala, rahang bawah dan kondisi psikologis dengan motivasi menurundan melakukan hal hal sederhana yang dapat dilakukan. Lanjut usia cenderung kurang membayangkan hal-hal yang baru di pelajari. Mereka tidak terlalu termotivasi untuk mengingat dikarenakan kurangnya fokus dan pendengaran yang kurang. Perubahan terhadap kesehatan dan fisik dapat terlihat dari keinginan mencari kegiatan yang dilakukan seperti duduk terus menerus dan penurunan keinginan melakukan kegiatan yang membutuhkan fisik dan tenaga seperti membersihkan, mencuci, menyapu dan lainnya.

Maka dari itu memerlukan suatu kegiatan yang sifat nya rekreatif, santai dan melatih kemampuan sensorik maupun motorik, serta mengembangkan dengan secara berkelompok.

\section{SIMPULAN}

Integrasi Pelayanan sosial di Balai Perlindungan Sosial Tresna Werdha Ciparay dalam mempengaruhi penyesuaian diri lanjut usia dalam menghadapi penolakan yang ada pada diri lanjut usia terhadap dirinya maupun lingkungan sosialnya. Terutama menghadapi proses transformasi dalam kehidupan diantaranya kehilangan pasangan hidup dan pindah ke panti jompo. Masalah utama yang dihadapi lanjut usia adalah penurunan kesehatan fisik dan mental yang membuat penyesuaian diri terhadap 
pelayanan sosial meliputi lingkungan alamiah, diri sendiri dan lingkungan sosial nya. Pelayanan sosial yang ada dapat merepresentasikan bagaimana negara menjalankan fungsi perlindungan dan perawatan lanjut usia jangka panjang(long term care).

Lanjut usia menghadapi tahapan proses kemunduran fisik maupun mental meliputi indera perasa, suara, mulut, kulit, kemampuan motorik, intelektual, sistem saraf dan otot, pernafasan, jantung, seksualitas mempengaruhi aktifitas sehari-hari, Lanjut usia menjalani kehidupannya dikategorikan menjadi dua sikap pertama, masa tua diterima dengan wajar melalui kesadaran mendalam. Kedua, cenderung menolak datangnya masa tua dan tidakmenerima kenyataan.

Penelitian menggunakan pendekatan kualitatif dengan indepth interview dan menggunakan pendekatan studi kasus secara purposive sampling dalam menentukan informan. Selain itu memperhatikan uji kredibilitas data meliputi ketekunan pengamatan, triangulasi sumber, teknik, waktu serta kecukupan referensi selanjutnya hasil penelitian ini dilakukan uji transferabilitiy yaitu pengujian hasil penelitian dapat diterapkan dimana dilakukan secara lengkap, jelas, sistematis dan dapat di pertanggungjawabkan. Selanjut nya melakukan uji dependability dan confirmability dimana dimaksudkan sebagai langkah mengaudit langkah yang diperoleh melalui konsultasi kepada tenaga ahli/ dosen pembimbing, sehingga data yang dihasilkan benar-benar dapat dipertanggung jawabkan.

Terdapat dua jenis standar panti sosial, diantaranya standar panti secara umum dan khusus. Standar panti secara umum yaitu aturan atau wewenang yang memuat kondisi lingkungan sekitar institusi yang memberikan layanan dan kinerja tertentu untuk mencapai tujuan serta memperbaiki pelaksanaan kegiatan yang ada apapun jenis permasalahannya. Sementara itu standar panti secara khusus diartikan meliputi aturan/ wewenang memuat dan berisi hal penting dan perlu perbaikan bagi berjalannya penyelenggaraan panti dan lembaga pelayanan sosialsejenis lainnya disesuaikanke khasan permasalahan yang di tangani panti.

Standar panti secara umum, ialah institusi atau panti sendiri memiliki strutur Kelembagaan, meliputiLegalitas Organisasi, Visi dan Misi, Organisasi dan Tata Kerja, Sumber Daya Manusia (penyelenggara panti, Pengembangangn Personil Panti, fasilitas umum, finansial, pelayanan sosial dasar, Monitoring dan Evaluasi. Maka integrasi layanan sosial memiliki peran dalam membantu lanjut usia dalam menjalani masa tua nya yang berkualitas serta mempromosikan layanan terintegrasi guna mendukung sistem layanan maupun kerja sama antar profesi yang ada di institusi yang memiliki penyelenggaraan layanan yang sejenis.

Penyesuaian diri adalah faktor penting dalam kehidupan manusia. Begitu pentingnya hal ini hingga berbagai literatur terdapat ungkapan bahwa manusia hidup sejak lahir hingga meninggal adalah penyesuaian diri. Penyesuaian diri dibagi menjadi 3 aspek yang dapat melihat proses dan bentuk penyesuaian diri diantaranya penyesuaian diri terhadap lingkungan alamiah nya (makanan, pakaian dan tempat tinggal), dirinya sendiri (the self) atau kondisi emosional dan kematangan emosi serta wawasan intelektual dalam menghadapi perubahan dan lingkungan sosial sebagaimana dapat berperan aktif dilingkungan sosialnya baik antar rekan sesama lanjut usia, terhadap pegawai panti maupun masyarakat. Sehingga memberikan bentuk penyesuaia diri yang baik atau buruk. Pelayanan sosial yang ada dapat memberikan suatu program kegiatan yang dapat membantu lanjut usia dalam meningkatkan penyesuaian diri serta sumber daya bagi profesi di layanan sejenis dengan mendukung perubahan ke arah positif baik dalam mempromosikan pelayanan terintegrasi maupun meningkatkan kualitas layanan serta lanjut usia mendapatkan perlindungan dan rasa aman serta mampu menghadapi kompleksitas masalah yang dihadapi dikarenakan penurunan kondisi fisik, psikologis dan mental dengan menikmati masa tua selama di panti.

\section{DAFTAR PUSTAKA}

Alex, S. (2013). Psikologi Umum (dalam lintasan sejarah). Cetakan ke-5. Bandung: Pustaka Setia.

Azizah, L.M.R, (2011). Keperawatan Lanjut Usia. Edisi 1. Yogyakarta: Graha Ilmu.

Badan Pusat Statistik. (2014). Statistik Penduduk Lanjut Usia 2017. Survei Sosial Ekonomi Nasional Jakarta: Badan Pusat Statistik Indonesia.

Brandl, B. (2007). Elder abuse detection and intervention a collaborative approach. New York: Springer Publishing Company.

Cronbach, L.J. (1963). Educational Psychology. New York: Harcourt, Brace \& World Inc.

Desmita, (2009). Psikologi Perkembangan. Bandung: Remaja Rosda Karya.

Heru, S.D. (1991). Profesi Pekerjaan Sosial dan Proses Pertolongannya. Bandung: Koperasi Mahasiswa STKS Bandung.

Hurlock, E.B. (1980). Psikologi Perkembangan: Suatu Pendekatan Sepanjang Rentang Kehidupan. Edisi kelima. Jakarta: Erlangga.

Huruswati, I., Purwanto, A., Sabarisman, M., Suyanto, \& Syawie, M. (2013). Pengembangan Kebijakan, Strategi dan Model Pelayanan Terpadu dan Gerakan Masyarakat Peduli Kabupaten/ Kota Sejahtera (pandu gempita) Kajian Kebijakan. Jakarta: P3KS Press.

Juliardi, B. (2014). Pendidikan Kewarganegaraan untuk Perguruan Tinggi. Jakarta: PT. Raja Grafindo Persada. 
Lalenoh, T. (1993). Gerontologi dan Penyesuaian Lanjut Usia. Bandung. STKS Bandung.

Maeda, D. (2000). The socioeconomic context of japanese social policy for aging.In Long, Susan Orpet (Ed.). Caring for the elderly in japan and the u.s practicies and policies (pp. 28-51). London and New York: Routledge.

Moenir, (2006), Manajemen Pelayanan Umum di Indonesia, Jakarta: Bumi Aksara
Siporin, M (1975), Introduction to Social Work Practice, New York Macmillan Publishing. Co, Inc.

Sunarto \& Hartono, A. (2008). Perkembangan Peserta Didik. Jakarta: Rineka Cipta.

Suharto,E.(2009). MembangunMasyarakatMemberdayakan Masyarakat. (Bandung: PT Refika Aditama). 